\title{
Nitrate reductase activity in macroalgae and its vertical distribution in macroalgal epiphytes of seagrasses
}

\author{
E. B. Young ${ }^{1,3, *}$, P. S. Lavery ${ }^{2}$, B. van Elven ${ }^{2}$, M. J. Dring ${ }^{1}$, J. A. Berges $^{1,3}$ \\ ${ }^{1}$ Marine Systems Group, School of Biology and Biochemistry, Queen's University of Belfast, Belfast BT9 7BL, UK \\ ${ }^{2}$ Centre for Ecosystem Management and School of Natural Sciences, Edith Cowan University, Joondalup, \\ Western Australia 6027, Australia
}

${ }^{3}$ Present address: Department of Biological Sciences, University of Wisconsin-Milwaukee, PO Box 413, Milwaukee, Wisconsin 53201, USA

\begin{abstract}
Macroalgal epiphytes within seagrass meadows make a significant contribution to total primary production by assimilating water column $\mathrm{N}$ and transferring organic $\mathrm{N}$ to sediments. Assimilation of $\mathrm{NO}_{3}{ }^{-}$requires nitrate reductase (NR, EC 1.6.6.1); NR activity represents the capacity for $\mathrm{NO}_{3}{ }^{-}$assimilation. An optimised in vitro assay for determining $\mathrm{NR}$ activity in algal extracts was applied to a wide range of macroalgae and detected NR activity in all 22 species tested with activity 2 to $290 \mathrm{nmol} \mathrm{NO}_{3}{ }^{-} \mathrm{min}^{-1} \mathrm{~g}^{-1}$ frozen thallus. With liquid- $\mathrm{N}_{2}$ freezing immediately after sample collection, this method was practical for estimating NR activity in field samples. Vertical distribution of NR activity in macroalgal epiphytes was compared in contrasting Posidonia sinuosa and Amphibolis antarctica seagrass meadows. Epiphytes on $P$. sinuosa had higher mass-specific NR activity than those on A. antarctica. In $P$. sinuosa canopies, NR activity increased with distance from the sediment surface and was negatively correlated with $\left[\mathrm{NH}_{4}^{+}\right]$in the water but uncorrelated with $\left[\mathrm{NO}_{3}{ }^{-}\right]$. This supported the hypothesis that $\mathrm{NH}_{4}{ }^{+}$released from the sediment suppresses NR in epiphytic algae. In contrast, the vertical variation in NR activity in macroalgae on A. antarctica was not statistically significant although there was a weak correlation with $\left[\mathrm{NO}_{3}{ }^{-}\right]$, which increased with distance from the sediment. Estimated capacities for $\mathrm{NO}_{3}{ }^{-}$assimilation in macroalgae epiphytic on seagrasses during summer ( 24 and $46 \mathrm{mmol} \mathrm{N} \mathrm{m}{ }^{-2} \mathrm{~d}^{-1}$ for $P$. sinuosa and $A$. antarctica, respectively) were more than twice the estimated $\mathrm{N}$ assimilation rates in similar seagrasses. When the estimates were based on annual average epiphyte loads for seagrass meadows in other locations, they were comparable to those of seagrasses. We conclude that epiphytic algae represent a potentially important sink for water-column nitrate within seagrass meadows.
\end{abstract}

KEY WORDS: Nitrate reductase $\cdot$ Macroalgae $\cdot$ Seagrass epiphytes $\cdot$ Dissolved inorganic nitrogen $\cdot$ Ammonium $\cdot$ Nitrate $\cdot$ Irradiance

Resale or republication not permitted without written consent of the publisher

\section{INTRODUCTION}

Macroalgal epiphytes within seagrass meadows make a significant contribution to biomass (Paling \& McComb 2000) and total primary production of a meadow (Cambridge \& Hocking 1997), with production even exceeding that of their seagrass hosts, particularly under low light (Libes 1986). The detrimental effect of excessive epiphytic macroalgal growth on seagrass viability is well documented, particularly in areas with increasing anthropogenic nutrient inputs to coastal waters (Silberstein et al. 1986, Hauxwell et al. 2001, McGlathery 2001). However, in oligotrophic waters epiphytic macroalgae can play an important role in ecosystem function by contributing to the capture of scarce $\mathrm{N}$ resources from the water column and 
the transfer of relatively $\mathrm{N}$-rich organic matter to the sediments of seagrass meadows, promoting nutrient cycling (reviewed by McGlathery 2001).

Coastal waters off Western Australia have very low concentrations of inorganic $\mathrm{N}$, mostly in the form of nitrate, which in summer is typically $<0.6 \mu \mathrm{M}$ (Johannes et al. 1994), yet they support abundant seagrass communities with diverse macroalgal epiphyte assemblages (Lavery \& Vanderklift 2002). The contribution of epiphytes to the total $\mathrm{N}$ assimilation by seagrass meadows, and the extent to which epiphytic macroalgae compete for water column inorganic nitrogen, are poorly understood. The nitrogen requirements of seagrass meadows are also met by remineralisation of organic nitrogen in sediments and subsequent release of ammonium, much of which is rapidly assimilated by the seagrass and epiphytic communities and thus not released to the overlying water column (Lee \& Dunton 1999).

Hauxwell et al. (2001) measured a gradient in ammonium concentration in a Zostera marina canopy, with highest concentrations closest to the sediment surface. Ammonium is taken up rapidly, and often preferentially over nitrate, by both seagrasses and macroalgae (Thomas \& Harrison 1985, Paling \& McComb 1994, Pedersen et al. 1997). Although inorganic N regenerated in the sediments is known to be important in supporting seagrass production (Lee \& Dunton 1999), little is known about the relative importance of nitrate and ammonium for epiphytic algae, or the role of ammonium released from the sediment in determining nitrate use by algal epiphytes within the meadow. Dissolved inorganic $\mathrm{N}$ concentrations can be misleading because of rapid $\mathrm{N}$ uptake and turnover, so additional measures of nitrate assimilation are needed.

The capacity of algae to assimilate nitrate depends upon the enzyme nitrate reductase (NR, EC 1.6.6.1), which reduces nitrate to nitrite. NR activity is regulated in response to nitrate availability, is inhibited by ambient ammonium and is regarded as the rate-limiting step in uptake and assimilation of nitrate into amino acids (Dortch 1990, Solomonson \& Barber 1990). Measurement of NR activity has been reported in relatively few macroalgal species (see Hurd et al. 1995), but studies have observed a strong correlation between NR activity and rates of nitrate incorporation both in phytoplankton (Berges et al. 1995) and in macroalgae (Davison et al. 1984). We aimed to use NR activity to estimate the nitrate assimilating capacity of epiphytic algae in seagrass meadows. While NR allows epiphytes to use nitrate from the water column, the gradient in ammonium released from seagrass sediments may suppress NR expression in macroalgae closer to the sediment and thus influence the form of inorganic $\mathrm{N}$ being taken up and assimilated by macroalgae depending on vertical distance from the sediment.

Measurement of NR activity can be difficult and some earlier papers reported low or no activity using an in vitro assay for algal extracts (e.g. Thomas \& Harrison 1988, Corzo \& Niell 1991) and seagrass tissues (Touchette \& Burkholder 2001). Our preliminary results also failed to detect NR activity in seagrass leaves with this method. An alternative in situ assay measuring NR activity can yield higher activities (Corzo \& Niell 1991, Lartigue \& Sherman 2002), but in situ assays require tissue permeabilisation, which can confound interpretation (see Thomas \& Harrison 1988, Corzo \& Niell 1991, Hurd et al. 1995). Hurd et al. (1995) reported an improved in vitro method to assay NR activity which they tested on extracts of 6 macroalgal species. This method provides an algal-specific method for determining NR activity in seagrass epiphytes. Because the assay measures the activity of NR with substrates (i.e. $\mathrm{NO}_{3}{ }^{-}$and $\mathrm{NADH}$ [nicotinamide dinucleotide diphosphate, reduced form]) at saturating concentrations (i.e. a conventional $V_{\max }$ assay), the activity measured is normally considered to represent a potential maximum. However, as a rate-limiting enzyme, NR may often be substrate-saturated, so NR activity may correlate quite closely with in vivo incorporation rates (e.g. Berges et al. 1995).

In this study, we aimed to establish a robust in vitro NR assay and demonstrate broad applicability in a wide range of algal taxa from the northern and southern hemispheres. Using the Hurd et al. (1995) NR assay, optimised for our species, we tested the hypothesis that ammonium released from seagrass sediments suppresses NR activity in macroalgal epiphytes within seagrass canopies. With this aim, we determined the vertical distribution of NR activity in macroalgal epiphytes in relation to vertical profiles of ammonium and nitrate concentration within 2 contrasting seagrass meadow types. We also evaluated the potential contribution of epiphytic algae to total inorganic $\mathrm{N}$ assimilation by seagrass meadows by using NR as an estimate of nitrate assimilation capacity.

\section{MATERIALS AND METHODS}

Sampling of macroalgal epiphytes. Stems of Amphibolis antarctica ([Labill.] Sonder \& Aschers. ex Aschers) and leaves of Posidonia sinuosa (Cambridge \& Kuo) with resident macroalgal epiphyte communities were collected from monospecific seagrass meadows in Shoalwater Bay, south of Perth, Western Australia $\left(31^{\circ} 17^{\prime} \mathrm{S}, 115^{\circ} 42^{\prime} \mathrm{E}\right)$ in February 2001 at a depth of 2 to $5 \mathrm{~m}$ using SCUBA. Leaves or stems were divided into top, middle and lowest portions (corresponding, in $P$. 
sinuosa leaves, to 15 to $20 \mathrm{~cm}$ sections and, in $A$. antarctica stems, to the bottom $25 \mathrm{~cm}$ and two $10 \mathrm{~cm}$ sections above), and were blotted dry before freezing in liquid nitrogen within 15 min of collection.

Brown algal collections. Some samples for initial trials were transferred to the laboratory and stored in seawater tanks. Short incubations $(<1 \mathrm{~h})$ in tanks following initial collections resulted in a marked loss of activity (also seen in Enteromorpha sp. by Lartigue \& Sherman 2002), and thus storage of unfrozen samples was avoided. Macroalgae were collected from the intertidal or subtidal region, blotted dry and frozen in liquid nitrogen within 15 min of collection. Durvillaea potatorum (Labillardière) Areschoug, Macrocystis angustifolia Bory, Ecklonia radiata (C. Agardh) J. Agardh, Hormosira banksii (Turner) Decaisne, Cystophora torulosa R. Brown ex Turner and Sargassum sp. were collected from Ocean Reef, near Sorrento, Australia (38 28' S, $\left.144^{\circ} 43^{\prime} \mathrm{E}\right)$, in March 2000. Fucus serratus L., F. vesiculosus (L.) Lamour, F. spiralis L. and Laminaria digitata (Huds.) Lamour were collected from the intertidal region of Strangford Lough, at Portaferry, Northern Ireland $\left(54^{\circ} 23^{\prime} \mathrm{N}, 5^{\circ} 34^{\prime} \mathrm{W}\right)$, between November 2000 and February 2001. Several macroalgal species (listed in 'Nitrate reductase activity' below) were also collected from reefs and seagrass substrates at Point Peron $\left(32^{\circ} 20^{\prime} \mathrm{S}, 115^{\circ} 42^{\prime} \mathrm{E}\right)$ and Mettam's Pool (31 $52^{\prime} \mathrm{S}$, $115^{\circ} 45^{\prime}$ E), near Perth, Australia, in February 2001.

Inorganic nitrogen and light profiles in seagrass meadows. Water was collected from sampling sites to characterise the vertical distribution of dissolved ammonium and nitrate availability within the seagrass meadows. Samples were collected manually using syringes attached by $1.5 \mathrm{~m}$ lengths of tubing to a cord, which was maintained vertical by a weight at the bottom and a float at the top. The tubing allowed water to be collected by the syringes distant from the vertical profile. The set-up was left in place for several minutes to minimise turbulence prior to sampling. Additional manual samples were taken using a syringe at the sediment surface $(<1.5 \mathrm{~cm})$. Duplicate profiles were sampled within each meadow at least $15 \mathrm{~m}$ apart and within $10 \mathrm{~min}$ of each other. Duplicate light attenuation profiles within Posidonia sinuosa and Amphibolis antarctica meadows were measured using a 2 pi quantum photometer (Li-Cor) attached to the top of a metal stake. PAR measurements were recorded at $50 \mathrm{~mm}$ intervals through the canopy by driving the stake into the sediment. To control for fluctuations in solar irradiance during the profiling period, PAR measurements were integrated over 1 min at each measuring point and all measurements were taken around midday on a cloudless day.

Nitrate reductase activity. NR activity was measured using the in vitro assay described by Hurd et al. (1995), modified and optimised for Fucus serratus, F. spiralis and F. vesiculosus. NR was extracted using a homogenisation buffer, which prevents NR degradation or oxidation, and assayed with saturating concentrations of $\mathrm{NADH}(0.2 \mathrm{mM})$ and $\mathrm{NO}_{3}{ }^{-}(10 \mathrm{mM})$. The production of $\mathrm{NO}_{2}^{-}$(resulting from $\mathrm{NO}_{3}^{-}$reduction) was monitored in replicate samples, by stopping the reaction with $\mathrm{Zn}$ acetate at given times, and measuring $\mathrm{NO}_{2}^{-}$using a standard spectrophotometric method. Hurd et al. (1995) determined that the addition of EDTA, bovine serum albumin (BSA), DL-dithiothreitol (DTT), polyvinylpyrolidone (PVP) and the detergent Triton X-100 (all Sigma) to the phosphate homogenising buffer helped maintain maximal NR activity. The effect of higher concentrations of Triton X-100 in the homogenisation medium on NR activity was tested in $F$. vesiculosus and a range of epiphytic algal species. Frozen macroalgal epiphytes on seagrasses were removed with a razor blade and ground in liquid $\mathrm{N}_{2}$ and homogenised $(0.1 \mathrm{~g}$ tissue with $1 \mathrm{ml}$ cold extraction buffer), using a glass tube and Teflon pestle. For 2 species, this homogenising method was compared with using a commercial homogeniser (Ultra-turrax, Ika Works). The effects of PVP and the inclusion of flavin adenine dinucleotide (FAD disodium salt, Sigma) in the assay were tested for 5 macroalgae, representative of epiphyte taxa present on the seagrasses: Dictyota sp., (Phaeophyta), Hypnea sp. (Rhodophyta), Corallina sp. (Rhodophyta), and Enteromorpha sp. (Chlorophyta). The effect of BSA (Fraction V Sigma) in the homogenisation medium was tested on Laurencia majuscula (Harvey) Lucas (Rhodophyta) and Dictyota sp. NR activity was also measured in Colpomenia peregrina (Sauvageau) Hamel (Phaeophyta). The final buffer composition used for homogenising epiphytic algae in determination of NR profiles was $200 \mathrm{mM}$ sodium-phosphate buffer, $\mathrm{pH} 7.9$, with $0.3 \%$ (w/v) PVP, 2 mM DTT, $5 \mathrm{mM} \mathrm{Na}_{2}$-EDTA, $3 \%$ (w/v) BSA, and $1 \%$ (v/v) Triton X-100 (all Sigma). The assay was carried out in $200 \mathrm{mM} \mathrm{Na}-\mathrm{PO}_{4}$ buffer, $\mathrm{pH} 7.9$, with $0.2 \mathrm{mM}$ NADH ( $\beta$ form, Sigma), 0.02 mM FAD (Sigma), $20 \%$ assay volume as algal extract and $10 \mathrm{mM} \mathrm{KNO}_{3}$ added to start the reaction at ambient temperature: $22^{\circ} \mathrm{C}$ for Western Australian algae, corresponding to March water temperature in Perth coastal waters, $13^{\circ} \mathrm{C}$ for Irish seaweeds, or $16^{\circ} \mathrm{C}$ for $\mathrm{SE}$ Australian seaweeds (which were also assayed without FAD). The reaction was terminated with $1 \mathrm{M}$ zinc acetate at time intervals 0 to 15 or 0 to 60 and the concentration of $\mathrm{NO}_{2}{ }^{-}$formed was measured as described below. NR activity was calculated using linear regression of increasing $\mathrm{NO}_{2}^{-}$ concentration over time. Extracts of Dictyota sp., Corallina sp., Entermorpha sp., Laurencia majuscula, and Champia zostericola (Harvey) Reedman \& Womersley (Rhodophyta) were individually assayed and compared with an assay where extracts of these 
algae were mixed in equal proportions and assayed as a pooled sample.

Analysis of ammonium, nitrate and nitrite. For the NR assays, nitrite was analysed spectrophotometrically according to Parsons et al. (1984). Nitrate plus nitrite in seawater samples was analysed in duplicate using an autoanalyser (Technicon). Ammonium concentration was estimated in duplicate samples from each sample using the fluorometric method of Holmes et al. (1999) with a Turner Designs 10AU fluorometer (Turner Systems).

Biomass estimation and total meadow nitrate assimilation. Epiphytic algal biomass on 10 stems of Amphibolis antarctica and 10 leaves of Posidonia sinuosa from the Shoalwater Bay sites was removed with a razor blade, described by Kendrick \& Lavery (2001), and frozen in liquid $\mathrm{N}_{2}$ for determination of frozen mass. The samples were subsequently thawed, ovendried at $60^{\circ} \mathrm{C}$ and the relationship between frozen and dry mass determined by regression, separately for $A$. antarctica and $P$. sinuosa epiphyte assemblages. These relationships were used to convert NR activity from a frozen to a dry mass basis, and to estimate total NR activity in epiphyte biomass represented on each portion of leaf or stem.

The $\mathrm{NO}_{3}{ }^{-}$assimilation capacity represented by biomass-specific NR activity levels in macroalgal epiphytes was converted to an areal basis using the measurements of epiphyte biomass per leaf or stem (above) and published estimates of shoot density (a monospecific Posidonia sinuosa meadow from Shoalwater Bay of 956 shoots $\mathrm{m}^{-2}$ [Cambridge \& Hocking 1997] and a median shoot density of 750 shoots $\mathrm{m}^{-2}$ from a range reported for Amphibolis spp. meadows in Perth coastal waters [Kendrick et al. 1998]).

$\mathrm{NO}_{3}{ }^{-}$assimilation can be defined as the reduction of $\mathrm{NO}_{3}{ }^{-}$into amino acids, whereas $\mathrm{N}$ incorporation involves reduction of inorganic $\mathrm{N}$ to macromolecules including proteins. Estimates of potential $\mathrm{NO}_{3}{ }^{-}$assimilation rates for the macroalgae were compared with estimates of $\mathrm{N}$ incorporated into above-ground new growth by seagrasses, excluding epiphytes, calculated from published values of $25.6 \mathrm{mg} \mathrm{N} \mathrm{m}^{-2} \mathrm{~d}^{-1}$ for Posidonia australis and $49.7 \mathrm{mg} \mathrm{N} \mathrm{m}^{-2} \mathrm{~d}^{-1}$ for Amphibolis antarctica in Shark Bay (Walker \& McComb 1988). To conservatively account for the discrepancy between $\mathrm{N}$ assimilation and $\mathrm{N}$ incorporation, the lowest incorporation efficiency of $16 \%$ in the seagrass Thalassia testudinum reported by Lee \& Dunton (1999) was used to convert $\mathrm{N}$ incorporation to $\mathrm{N}$ assimilation rates for the seagrass component.

Data analysis. Differences in NR activity between different leaf or stem portions were evaluated separately for each seagrass using a 1-way ANOVA with a Tukey-Kramer pairwise post-hoc analysis testing for significance at $\mathrm{p}<0.05$ (SigmaStat, SPSS). NR activity in epiphytes from the 2 seagrass meadows were compared with a 2-way ANOVA (SigmaStat). Light attenuation between the meadows was compared using a paired $t$-test (SigmaStat).

\section{RESULTS}

\section{Optimisation of nitrate reductase assay}

Application of the optimised in vitro NR assay yielded NR activity in all macroalgal species tested. Assays of NR activity in Fucus species showed that increasing the concentration of Triton X-100 from $0.1 \%$, used by Hurd et al. (1995), to $1 \%$ dramatically increased the NR activity extracted (results from present study [see Fig. 1A, Table 1] and from previous studies [see Table 1]). Increasing the Triton X-100 concentration from 1 to $2 \%$ did not yield higher NR activity from any of the test species (Fig. 1A, other species not shown, $\mathrm{n}=3$ ). The NR activity in Fucus species from Ireland was the highest, exceeding previous esti-

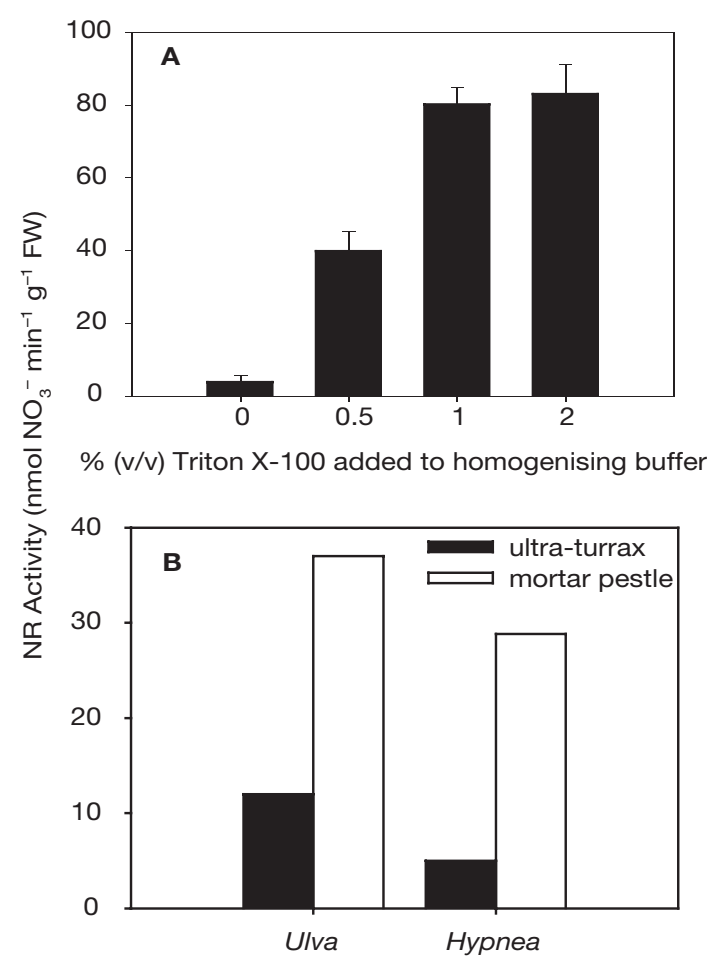

Fig. 1. Effect of homogenising conditions on nitrate reductase (NR) activity measured in macroalgal extracts. (A) Effect of different concentrations of Triton X-100 in the homogenising buffer on NR activity measured in Fucus vesiculosus. Extracts were homogenised with a mortar and pestle. Bars are mean; error bars are $\mathrm{SD}, \mathrm{n}=3$. (B) Effect of manual glass mortar and Teflon pestle versus a commercial homogeniser on yield of NR activity in Ulva sp. and Hypnea sp., $\mathrm{n}=1$. FW: frozen thallus weight 
mates nearly 10-fold (Table 1). In epiphytic algae from Western Australia, the highest NR activities were measured in Ulva and Hypnea species, at approximately $50 \mathrm{nmol} \mathrm{NO}_{3}^{-} \mathrm{min}^{-1} \mathrm{~g}^{-1}$ frozen thallus weight (FW), and a minimum activity in any extract of $2 \mathrm{nmol} \mathrm{NO}_{3}{ }^{-} \mathrm{min}^{-1}$ $\mathrm{g}^{-1}$ FW. The method of homogenisation was important in the yield of NR activity extracted from thalli. A 3- fold higher activity was measured in Ulva and Hypnea species when using a glass tube and mechanically driven close-fitting Teflon pestle compared to extracts made using an Ultra-Turrax tissue homogeniser, even when ground with identical buffer (Fig. 1B). The NR activity yield was not affected by inclusion or exclusion of $0.3 \%$ insoluble PVP. Although the inclusion of FAD

Table 1. Comparison of maximum nitrate reductase (NR) activities measured in extracts of macroalgae from a range of taxonomic groups, using the in vitro method and normalised to frozen weight (FW). Where included, measures of variation are standard deviation unless indicated otherwise (SE = standard error). W Aust: Perth coastal waters, Western Australia; SE Aust: Sorrento, Victoria; Ireland: Strangford Lough, N. Ireland. FAD: flavin adenine dinucleotide

\begin{tabular}{|c|c|c|c|}
\hline $\begin{array}{l}\text { Species (sampling site } \\
\text { or laboratory cultured) }\end{array}$ & $\begin{array}{l}\text { Max. NR activity } \\
\left(\text { nmol } \mathrm{NO}_{3}^{-} \mathrm{min}^{-1} \mathrm{~g}^{-1} \mathrm{FW}\right)\end{array}$ & $\begin{array}{l}\text { Notes/ } \\
\text { comments }\end{array}$ & Source \\
\hline \multicolumn{4}{|l|}{ Phaeophyta } \\
\hline Macrocystis integrifolia (BC, Canada) & $9.61( \pm 1.8)$ & \multirow{4}{*}{${ }^{\mathrm{a}}(1.8 \mathrm{mM})$} & Hurd et al. (1995) \\
\hline Macrocystis angustifolia (South Africa) & 3.3 & & Haxen \& Lewis (1981) \\
\hline Macrocystis angustifolia (Cultured) & 11.7 & & Haxen \& Lewis (1981) \\
\hline Laminaria digitata (Scotland) & 5.3 & & Davison \& Stewart (1984a) \\
\hline Laminaria digitata (Ireland) & $60( \pm 5.4)$ & \multirow[t]{2}{*}{$+\mathrm{FAD}$} & Present study \\
\hline Fucus gardneri (BC, Canada) & $35.99( \pm 1.58)$ & & Hurd et al. (1995) \\
\hline Fucus serratus (Ireland) & $165( \pm 18)$ & $+\mathrm{FAD}$ & Present study \\
\hline Fucus spiralis (Ireland) & $273( \pm 8)$ & $-F A D$ & Present study \\
\hline Fucus vesiculosus (Ireland) & $290( \pm 15)$ & $-F A D$ & Present study \\
\hline Pelvetia canaliculata (Ireland) & $122( \pm 9.8)$ & $-\mathrm{FAD}$ & Present study \\
\hline Dictyota sp. (W Aust) & $40.6( \pm 1.6)$ & $+\mathrm{FAD}$ & Present study \\
\hline Sargassum sp. (W Aust) & 10.8 & $+\mathrm{FAD}$ & Present study \\
\hline Sargassum sp. (SE Aust) & 31.9 & b & Present study \\
\hline Ecklonia radiata (SE Aust) & 16.7 & $\mathrm{~b}$ & Present study \\
\hline Durvillaea potatorum (SE Aust) & 4.5 & $\mathrm{~b}$ & Present study \\
\hline Cystophora torulosa (SE Aust) & 4.5 & $\mathrm{~b}$ & Present study \\
\hline Hormosira banksii (SE Aust) & 1.8 & $\mathrm{~b}$ & Present study \\
\hline Macrocystis angustifolia (SE Aust) & 5.5 & $\mathrm{~b}$ & Present study \\
\hline Colpomenia peregrina (W Aust) & 2.5 & & Present study \\
\hline \multicolumn{4}{|l|}{ Rhodophyta } \\
\hline Porphyra yezoensis (Japan) & 33.2 & \multirow{12}{*}{ a $(500 \mu \mathrm{M})$} & Araki et al. (1979) \\
\hline Porphyra perforata (BC, Canada) & 20.8 & & Thomas \& Harrison (1988) \\
\hline Porphyra sp. (BC, Canada) & $4.0( \pm 0.96)$ & & Hurd et al. (1995) \\
\hline Corallina vancouvensis (BC, Canada) & $22.6( \pm 1.31)$ & & Hurd et al. (1995) \\
\hline Corallina sp. (W Aust) & $30.8( \pm 2.1)$ & & Present study \\
\hline Laurencia majuscula (W Aust) & $3.4( \pm 1.6)$ & & Present study \\
\hline Chondrous crispus (Ireland) & $108( \pm 17)$ & & Present study \\
\hline Palmaria palmata (Ireland) & $9.7( \pm 3.7)$ & & Present study \\
\hline Hypnea sp. (W Aust) & $48.7( \pm 1.9)$ & & Present study \\
\hline Champia sp. (W Aust) & $17.1( \pm 1.3)$ & & Present study \\
\hline Gracilaria tenuisipitata (Cultured) & 43.3 & & Lopes et al. (1997) \\
\hline Gelidium sp. (AL, USA) & $11.50( \pm 0.33 \mathrm{SE})$ & & Lartigue \& Sherman (2002) \\
\hline \multicolumn{4}{|l|}{ Chlorophyta } \\
\hline Ulva sp. (AL, USA) & $3.67( \pm 0.17 \mathrm{SE})$ & & Lartigue \& Sherman (2002) \\
\hline Ulva sp. (BC, Canada) & $9.3( \pm 1.6)$ & & Hurd et al. (1995) \\
\hline Ulva sp. (Ireland) & $45.9( \pm 14.2)$ & & Present study \\
\hline Ulva sp. (W Aust) & $37.3( \pm 5.4)$ & & Present study \\
\hline Enteromorpha sp. (AL, USA) & $9.67( \pm 1.17 \mathrm{SE})$ & & Lartigue \& Sherman 2002) \\
\hline Enteromorpha (BC, Canada) & 26.7 & & Hurd et al. (1995) \\
\hline Acetabularia mediterranea (Cultured) & 120 & c & Balandin \& Aparicio (1992) \\
\hline \multicolumn{4}{|c|}{ Key to localities in this study: } \\
\hline \multicolumn{4}{|c|}{${ }^{\mathrm{a}} \mathrm{NO}_{3}{ }^{-}$enriched preincubation conditions $\left(\mathrm{NO}_{3}{ }^{-}\right.$concentration in parentheses) } \\
\hline \multicolumn{4}{|c|}{${ }^{\mathrm{b}}$ Assayed without FAD; effect of FAD not tested } \\
\hline \multicolumn{4}{|c|}{$\begin{array}{l}\text { 'NR activity per protein converted to per mass using a value of } 10 \mathrm{mg} \text { protein } \mathrm{g}^{-1} \text { wet weight from A. mediterranea, or } 25 \mathrm{mg} \\
\text { protein } \mathrm{g}^{-1} \text { wet weight used by Hurd et al. (1995) for Pophyra perforata }\end{array}$} \\
\hline
\end{tabular}



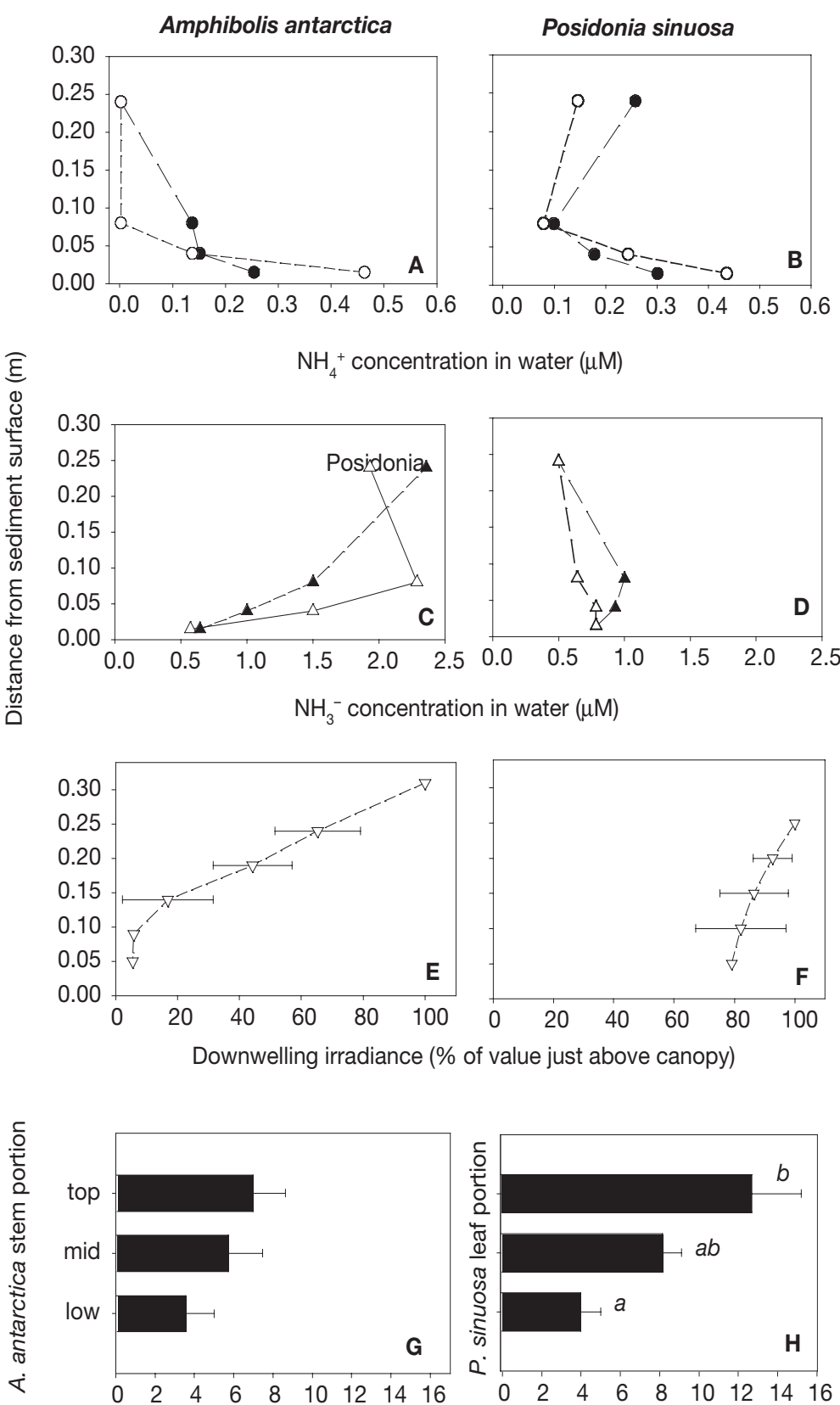

NR Activity (nmol $\left.\mathrm{NO}_{3}^{-} \mathrm{min}^{-1} \mathrm{~g}^{-1} \mathrm{FW}\right)$

Fig. 2. Dissolved inorganic nitrogen concentrations, irradiance and NR activity in epiphytic algae over a vertical gradient from the sediment surface in $(\mathrm{A}, \mathrm{C}, \mathrm{E}, \mathrm{G})$ Amphibolis antarctica and $(\mathrm{B}, \mathrm{D}, \mathrm{F}, \mathrm{H})$ Posidonia sinuosa meadows in Shoalwater Bay, Western Australia. (A-D) Vertical profiles through the water column and canopy of $(\mathrm{A}, \mathrm{B}) \mathrm{NH}_{4}{ }^{+}$and $(\mathrm{C}, \mathrm{D}) \mathrm{NO}_{3}{ }^{-}+$ $\mathrm{NO}_{2}{ }^{-}$concentration. Plots show duplicate profiles sampled through each meadow type. (E,F) Light attenuation through the canopy of $A$. antarctica and $P$. sinuosa meadows (mean $\pm \mathrm{SD}, \mathrm{n}=2)$. $(\mathrm{G}-\mathrm{H})$ Vertical distribution of mean NR activity ( $+1 \mathrm{SD})$ in algal epiphytes from $A$. antarctica and $P$. sinuosa meadows, $\mathrm{n}=6$ to 14 . low: epiphytes removed from the seagrass stem or leaf closest to the sediment surface; mid: epiphytes removed from middle part of seagrass stem or leaf; top: epiphytes removed from portion of seagrass furthest from the sediment (see text for details). Bars with statistically different values are labelled with different letters in the assay improved activity in Fucus serratus and Laminaria digitata, it did not significantly elevate activity in F. spiralis, F. vesiculosus, and the epiphytic species Corallina sp., Hypnea sp., Dictyota sp. or Enteromorpha sp., although NR activity was highly variable among replicate plants of Dictyota sp. and Enteromorpha sp. ( $\mathrm{n}=3$ to 6 ). The exclusion of BSA from the homogenisation buffer resulted in a 25 to $40 \%$ decline in measured NR activity in extracts of $F$. vesiculosus, Laurencia majuscula and Dictyota sp. ( $\mathrm{n}=3$; not shown). In a combined assay, there was only a very minor inhibition of NR activity in each species by the inclusion of extracts of other species; individually assayed extracts of the epiphytic algae yielded a mean NR activity of $2.86 \mathrm{nmol} \mathrm{NO}_{3}{ }^{-}$ $\mathrm{min}^{-1} \mathrm{~g}^{-1} \mathrm{FW}$ and in the pooled sample, the NR activity was $2.65 \mathrm{nmol} \mathrm{NO}_{3}^{-} \min ^{-1} \mathrm{~g}^{-1} \mathrm{FW}$, within $7 \%$ of the mean value.

\section{Nutrient and light profiles in seagrass meadows}

Dissolved inorganic nitrogen concentrations were low in the open coastal water sampled in replicate vertical profiles through seagrass meadows in Shoalwater Bay (Fig. 2A-D). In both Amphibolis antarctica and Posidonia sinuosa meadows, the trend was for a higher $\mathrm{NH}_{4}{ }^{+}$ concentration in the water close to the sediment surface (Fig. 2A,B). There was an increase in $\mathrm{NO}_{3}{ }^{-}$concentration with distance from the sediment in the A. antarctica meadows but no statistically significant vertical variation in $\mathrm{NO}_{3}{ }^{-}$concentration in $P$. sinuosa meadows (Fig. 2C,D). The lowest $\mathrm{NH}_{4}{ }^{+}$concentration within the seagrass canopy and in the overlying water column was observed in the A. antarctica meadows. The concentration of $\mathrm{NH}_{4}{ }^{+}$and $\mathrm{NO}_{3}{ }^{-}$at the sediment surface was similar ( 0.3 to $0.5 \mu \mathrm{M}$ for $\mathrm{NH}_{4}{ }^{+}$and 0.6 to $0.8 \mu \mathrm{M}$ for $\mathrm{NO}_{3}^{-}$) in both seagrass types. In the overlying water column, $\mathrm{NO}_{3}{ }^{-}$concentrations were higher in A. antarctica than in P. sinuosa meadows, but the $\mathrm{NH}_{4}{ }^{+}$concentrations were more similar $(<0.5 \mu \mathrm{M})$ above both meadow types.

The attenuation of PAR through the canopy was significantly greater in the Amphibolis antarctica meadow than in the Posidonia sinuosa meadow (<0.001) (Fig. 2E,F). Mean canopy attenuation coefficients were $10.9 \pm 3.7$ and 1.3 $\pm 1.1 \mathrm{~m}^{-1}(\mathrm{n}=2)$, respectively, for A. antarctica and $P$. sinuosa canopies. 


\section{Vertical distribution of NR activity}

NR activity measured in algal epiphytes from seagrass leaves increased with distance from the sediment surface in Posidonia sinuosa meadows (Fig. $2 \mathrm{H}_{i} \mathrm{p}=$ 0.0283, $F=4.053$, df 2, 28; 1-way ANOVA). Pairwise analysis suggested that the differences in NR activity in epiphytes from the lowest and uppermost portions of leaves of $P$. sinuosa were significant $(\mathrm{p}<0.05)$, but differences in NR activity of algae from the top and middle or lowest and middle portions of the leaves were not significant (Fig. 2H). While a similar trend was apparent for Amphibolis antarctica stems, this was not statistically significant ( $p>0.5$, Fig. 2G). NR activity in epiphytes sampled from $P$. sinuosa leaves was higher than the activity observed in epiphytes from $A$. antarctica stems ( $\mathrm{p}<0.008,2$-way ANOVA). When plotted against the vertical distribution of inorganic N (Fig. 3), the NR activity in epiphytic algae on A. antarctica showed a close negative correlation with $\mathrm{NH}_{4}{ }^{+}\left(\mathrm{r}^{2}=0.999\right.$; $\mathrm{NR}$ activity $\left.=-9.757\left[\mathrm{NH}_{4}{ }^{+}\right]+7.056\right)$ and positive correlation with $\mathrm{NO}_{3}{ }^{-}$concentration $\left(\mathrm{r}^{2}=0.991\right)$. The relationship between inorganic $\mathrm{N}$ concentration and NR activity in $P$. sinuosa epiphytes was less clear-cut; there was a fair correlation and negative relationship between NR activity and $\mathrm{NH}_{4}{ }^{+}$concentration $\left(\mathrm{r}^{2}=0.792\right.$; $\mathrm{NR}$ activity $=$ $-34.156 \times\left[\mathrm{NH}_{4}{ }^{+}\right]+17.421$ ) but no relationship to $\mathrm{NO}_{3}{ }^{-}$ concentration in the water column $\left(r^{2}=0.199\right)$. The $x$ intercepts for the linear relationship between NR activity and $\mathrm{NH}_{4}{ }^{+}$concentration (Fig. 3A) suggested that the ambient $\mathrm{NH}_{4}{ }^{+}$concentration required to achieve no NR activity was $1.38 \mu \mathrm{M}$ (A. antarctica epiphytes) and $1.96 \mu \mathrm{M}$ (P. sinuosa epiphytes).

\section{Distribution of epiphyte biomass and NR activity}

Maximum NR activity was used to derive the estimated $\mathrm{NO}_{3}{ }^{-}$assimilating capacity associated with macroalgal epiphyte assemblages. Even though the biomass-specific NR activity in Posidonia sinuosa epiphytes was higher (Fig. 2G,H), each Amphibolis antarctica stem supported twice the nitrate assimilation capacity of each $P$. sinuosa leaf because of the higher epiphytic macroalgal biomass (Table 2). The middle stem section of $A$. antarctica often supported large clumps of a single alga, evident in the vertical biomass distribution shown in Table 2. On P. sinuosa leaves, the greatest algal biomass accumulation was on the oldest, uppermost section of the leaf.

Using published estimates of shoot or leaf areal density (Cambridge \& Hocking 1997, Kendrick et al. 1998), the calculated area-specific $\mathrm{NO}_{3}{ }^{-}$assimilation capacity of Amphibolis antarctica epiphyte assemblages was estimated at almost double that of the epiphytes in

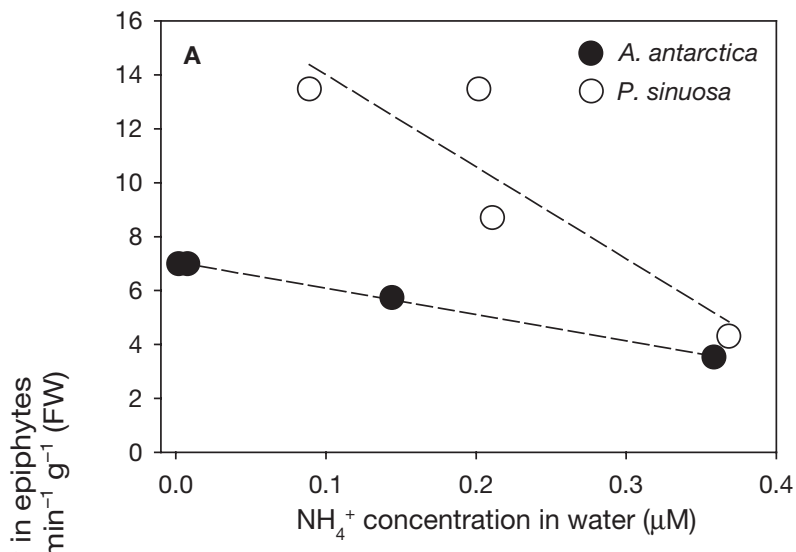

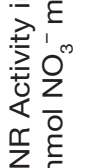

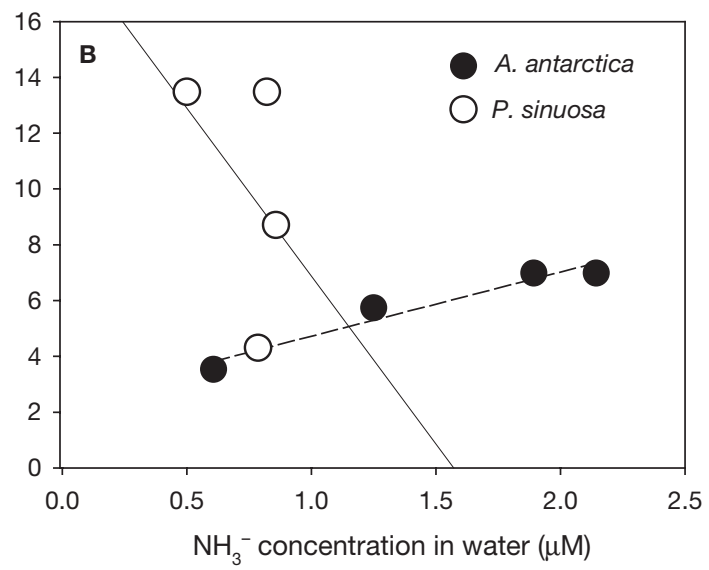

Fig. 3. NR activity in epiphytes on seagrasses plotted against (A) ambient ammonium and (B) nitrate concentrations in the water column. Lines are linear regressions (Sigmaplot): $\mathrm{r}^{2}=0.9986$ and 0.9906 for Amphibolis antarctica and $\mathrm{r}^{2}=$ 0.7922 and 0.1994 for Posidonia sinuosa for $\mathrm{NH}_{4}{ }^{+}$and $\mathrm{NO}_{3}{ }^{-}$, respectively

Posidonia sinuosa meadows (Table 2). In both seagrass types, the $\mathrm{N}$ assimilation capacity of the macroalgal epiphytes was more than double the estimated maximum rate of $\mathrm{N}$ acquisition by the seagrass component of the meadow.

\section{DISCUSSION}

\section{Nitrate reductase assay optimisation}

NR activity could be measured in all 22 species of algae from Ireland, SE Australia and Western Australia (Table 1). The optimised in vitro NR activity assay can be applied to diverse red, green and brown macroalgal taxa, despite previous reports indicating poor or no yield of NR activity in some species using an in vitro assay (Thomas \& Harrison 1988, Corzo \& Niell 1991). In Fucus and Laminaria species, the NR activity mea- 
can suppress the expression of NR in algae (Berges et al. 1995). The relationship between $\mathrm{NO}_{3}{ }^{-}$and $\mathrm{NH}_{4}{ }^{+}$ availability and NR expression in algae has been more comprehensively characterised in phytoplankton and is less well understood in macroalgae. However, suppression or inactivation of NR activity by the presence of $\mathrm{NH}_{4}{ }^{+}$is evident in Fig. 3A and has been shown in red macroalgae (Thomas \& Harrison 1985, Ganesan et al. 2001), in the brown alga Laminaria digitata (E. B. Young unpubl.), and in the green alga Acetabularia mediterranea (Balandin \& Aparicio 1992). If $\mathrm{NH}_{4}^{+}$ availability suppresses $\mathrm{NR}$ in epiphytic algae, $\mathrm{NH}_{4}^{+}$ diffusion from the sediments into the water column may result in the reduced NR activity levels observed in $P$. sinuosa epiphytes growing closer to the sediment surface. Extrapolation of the relationship between NR activity in macroalgal epiphytes and $\mathrm{NH}_{4}{ }^{+}$concentration (Fig. 3A) suggests that NR activity would be completely inhibited at water column concentrations between 1 and $2 \mu \mathrm{M}$. These values are close to that estimated by Dortch (1990) for complete inhibition of NR activity in phytoplankton.

The vertical profile in epiphytic macroalgal NR activity in Amphibolis antarctica was similar to that in Posidonia sinuosa but was not statistically significant. Greater replication may have reduced the variance in our data and possibly resulted in a significant trend in both seagrass types. In addition to a strong $\mathrm{NH}_{4}{ }^{+}$gradient through the $A$. antarctica, there was an opposing vertical profile in $\mathrm{NO}_{3}^{-}$(compare Fig. 2C and D, Fig. 3B) both of which are expected to influence the expression of NR activity in algae; NR expression requires the presence of $\mathrm{NO}_{3}{ }^{-}$(Solomonson \& Barber 1990) and there was a weak positive linear relationship between NR activity and $\mathrm{NO}_{3}{ }^{-}$concentration in $A$. antarctica epiphytes $\left(\mathrm{r}^{2}=0.991\right.$; Fig. 3B), although no clear-cut relationship was observed for P. sinuosa epiphytes (Fig. 3B). In phytoplankton, NR activity can be enhanced by the presence of low $\mathrm{NO}_{3}{ }^{-}$concentration, probably to ensure efficient assimilation of what $\mathrm{NO}_{3}{ }^{-}$ is available (Dortch 1990, Berges et al. 1995); recurrent or continual low $\mathrm{NO}_{3}{ }^{-}$concentration in Perth coastal waters (Johannes et al. 1994) may thus stimulate NR activity in seagrass epiphytes.

Despite the apparent similarity in the vertical trend in epiphyte NR activity through the canopies of both seagrass species, it is possible that the lack of statistical significance for the data from Amphibolis antarctica meadows reflects a real difference between the 2 seagrass communities. This could be due to several factors including $\mathrm{NO}_{3}{ }^{-}$and $\mathrm{NH}_{4}{ }^{+}$availability, light and epiphyte composition. It is unknown if the differences observed in water column $\mathrm{NO}_{3}{ }^{-}$concentrations between the 2 meadow types endure long enough to affect algal physiology and the extent to which inor- ganic $\mathrm{N}$ concentrations in seagrass meadows are seasonally or diurnally persistent, although this warrants further examination. Rapid turnover of $\mathrm{NH}_{4}^{+}$(and urea) excreted by epifauna on the seagrass host could also contribute to $\mathrm{NH}_{4}{ }^{+}$rather than $\mathrm{NO}_{3}{ }^{-}$uptake by algae and seagrasses, but this may not be evident from water column sampling. Light is an important environmental factor regulating NR activity in algae, stimulating both $\mathrm{NO}_{3}^{-}$uptake and expression of $\mathrm{NR}$ in macroalgae (Davison \& Stewart 1984b, Gao et al. 1992, Lopes et al. 1997). The branching habit and high epiphyte loads resulted in the relatively high attenuation of light observed in A. antarctica meadows (see also Brush \& Nixon 2002). However, the lack of a steep irradiance gradient in the Posidonia sinuosa meadow, where significant vertical variation in NR activity was observed, suggests that irradiance was not a major determinant of the observed trends in NR activity in seagrass epiphytes. The irradiance measured close to the sediment in $A$. antarctica and $P$. sinuosa were 40 and $800 \mu \mathrm{mol}$ photons $\mathrm{m}^{-2} \mathrm{~s}^{-1}$, respectively, neither of which represents growth-limiting values for most macroalgae (Dring 1982).

NR activity may also be related to differences between the 2 seagrasses in the vertical patterns of epiphyte composition and turnover rate of leaves and stems to which the epiphytes attach. For seagrasses with strap-like leaves, such as Posidonia sinuosa, the diversity, as well as biomass, of epiphytic algae is highest on the leaf apex (Trautman \& Borowitzka 1999). $P$. sinuosa leaves have an average longevity of $245 \mathrm{~d}$ (Marbà \& Walker 1999) and grow from the base, with the oldest part of the leaf at the top of the canopy where the greatest epiphyte biomass was observed (Table 2; Trautman \& Borowitzka 1999). This 'conveyer belt' of $P$. sinuosa leaf growth means that algae recruited to the younger leaf surface that remain attached to the leaf will be more mature when they reach the top of the leaf, a factor which may influence $\mathrm{NO}_{3}{ }^{-}$metabolism. This spatial pattern in maturity may contribute to a pronounced gradient of NR activity in epiphytes on $P$. sinuosa. Amphibolis species do not show the same spatial relationship with epiphyte recruitment as the strap-leafed species (Lavery \& Vanderklift 2002). Macroalgal biomass on A. antarctica was mostly found attached to the perennial stems, located in the middle section of the canopy (Table 2). This could eliminate any vertical gradient in NR activity amongst algal epiphytes related to age of algal epiphytes.

Leaving aside any possible differences in the vertical distribution of NR activity through the canopies, the NR rates on Posidonia sinuosa were clearly higher than those on Amphibolis antarctica. The current study did not include detailed analyses of species composition 
and there are few comparative studies of the epiphyte assemblages on different seagrasses. However, previous work has shown a significant variation in the composition of epiphytes among seagrass species (Trautman \& Borowitzka 1999, Lavery \& Vanderklift 2002). It is possible, therefore, that some of the differences in mass-specific NR activity between A. antarctica and $P$. sinuosa epiphytes were due to differences in the species composition.

\section{Ecosystem-level scaling}

Potential rates of $\mathrm{NO}_{3}{ }^{-}$assimilation, estimated from observed NR activity, demonstrated the considerable capacity of macroalgae in seagrass meadows to capture $\mathrm{NO}_{3}{ }^{-}$from the water column. Recent studies (e.g. Lee \& Dunton 1999) attempted to estimate annual $N$ budgets for seagrasses using measured inorganic $\mathrm{N}$ uptake rates. Using $\mathrm{NR}$ activity, the $\mathrm{NO}_{3}{ }^{-}$assimilating capacity of epiphytic algae was estimated to be more than double the $\mathrm{N}$ incorporation rates of seagrasses in both $\mathrm{Am}$ phibolis antarctica and Posidonia sinuosa meadows (Table 2). However, this may significantly overestimate the relative assimilation rates of epiphytic macroalgae, for 2 reasons. First, $\mathrm{N}$ incorporation estimates for the seagrasses were based on growth rates, and will underestimate the rate of $\mathrm{N}$ assimilation within seagrass tissues. We did correct for this using a published incorporation rate from the seagrass Thalassia testudinum, for which inorganic $\mathrm{N}$ uptake was found to be up to 6 times greater than $\mathrm{N}$ incorporation into new growth; this was attributed to excretion of dissolved inorganic and organic N (Lee \& Dunton 1999). Second, the epiphyte biomass recorded at Shoalwater Bay was high compared to other seagrass meadows in the region, principally as they are summer values, and seasonal temperature fluctuations may influence assimilation rates. While shoot densities remain similar in both species over an annual cycle (Cambridge \& Hocking 1997, Lavery et al. 1998), epiphyte loads vary significantly over a year. At Shoalwater Bay, in summer, the epiphyte load was approximately $0.225 \mathrm{~g}$ dry weight per $P$. sinuosa leaf and $2.3 \mathrm{~g}$ dry weight per $A$. antarctica stem. Over an annual cycle, Cambridge \& Hocking (1997) measured annual epiphyte biomass means of approximately $0.024 \mathrm{~g}$ shoot $^{-1}$ for $P$. sinuosa, and Lavery et al. (1998) estimated an annual average of $0.913 \mathrm{~g} \mathrm{shoot}^{-1}$ for Amphibolis griffithii, approximately 10 and $40 \%$ of those measured in February at Shoalwater Bay, respectively. This suggests that our estimates based on Shoalwater Bay data from summer are likely to be at the upper end of potential $\mathrm{NO}_{3}{ }^{-}$assimilation, and that annual averages could be about 1 order of magnitude lower than those we have estimated.
Allowing for these discrepancies, the $\mathrm{NO}_{3}{ }^{-}$assimilating capacity in macroalgal epiphytes was at least comparable to the estimated rate of $\mathrm{N}$ acquisition by Posidonia sinuosa or Amphibolis antarctica (Table 2), so epiphytic algae on these seagrasses represent a potentially major reservoir for water column $\mathrm{NO}_{3}{ }^{-}$. However, given the low $\mathrm{N}$ concentration in water around the meadows, and that NR is the rate-limiting enzyme in $\mathrm{NO}_{3}{ }^{-}$assimilation, $\mathrm{N}$ incorporation may be limited by availability of $\mathrm{NO}_{3}{ }^{-}$rather than by $\mathrm{NO}_{3}{ }^{-}$assimilation capacity. The potential contribution of epiphytes to total $\mathrm{N}$ assimilation in a seagrass meadow could be higher if the epiphytes assimilate significant amounts of $\mathrm{NH}_{4}{ }^{+}$from the water column. $\mathrm{NH}_{4}{ }^{+}$concentration in Perth coastal waters is very low, and $\mathrm{NO}_{3}{ }^{-}$is the dominant form of dissolved inorganic $\mathrm{N}$ (Johannes et al. 1994; Fig. 2) though epifaunal excretion may supply additional $\mathrm{NH}_{4}{ }^{+}$for uptake.

There are few estimates of NR activity from seagrasses, but Touchette \& Burkholder (2001) recently measured NR activity in Zostera marina using an in situ assay, and reported $8.3 \mathrm{nmol} \mathrm{NO}{ }_{3}{ }^{-} \mathrm{min}^{-1} \mathrm{~g}^{-1}$ tissue under ambient $\mathrm{NO}_{3}{ }^{-}$conditions. This is similar to the range of values observed for macroalgal epiphytes from Posidonia sinuosa and Amphibolis antarctica, although the in situ and in vitro assays may not be strictly comparable. The comparison of $\mathrm{N}$ incorporation by epiphytes versus seagrasses has not accounted for below-ground $\mathrm{N}$ acquisition by seagrasses, although estimates of this vary from half the total $\mathrm{N}$ acquisition in Thalassia testudinum (Lee \& Dunton 1999), to somewhat less in A. antarctica (Pedersen et al. 1997) and minimal in P. oceanica (Kraemer et al. 1997). However, the $\mathrm{N}$ incorporation values (Walker \& McComb 1988) we used were for above-ground biomass only. Furthermore, production rates of algal epiphytes are higher than those of seagrasses (Cambridge \& Hocking 1997), and macroalgae can also take up inorganic $\mathrm{N}$ faster than seagrasses (e.g. Pedersen 1994, cf. Pedersen et al. 1997), competing effectively for dissolved inorganic $\mathrm{N}$ in the water column.

Based on the above estimates, epiphytes could play a significant role in nitrate acquisition in both the seagrass meadow types we examined. Under oligotrophic conditions, epiphytes may confer a significant advantage to seagrass ecosystems by assimilating $\mathrm{N}$ and by reducing export of $\mathrm{N}$ from the meadow by contributing to the trapped detrital component of meadows. Within a tropical seagrass community, living seagrass only contained $6 \%$ of total $\mathrm{N}$, with over $90 \%$ total $\mathrm{N}$ represented in particulate detritus (Boon 1986), to which epiphytes make an important contribution. Of course any benefits conferred by macroalgal epiphytes on nutrient dynamics of seagrass meadows may be offset by a reduction of light reaching the seagrass leaves. 
However, in clear oligotrophic waters at low and moderate latitudes, this reduction is unlikely to limit growth, and epiphytes may also shield seagrasses from harmful UV radiation.

\section{SUMMARY AND CONCLUSIONS}

The improved in vitro NR assay was applicable to a diverse range of 22 macroalgal taxa; with liquid nitrogen freezing soon after collection, the assay can be used to estimate NR activity, and thus estimate a maximum $\mathrm{NO}_{3}^{-}$assimilation rate, in field samples. A decrease in the NR activity in Posidonia sinuosa epiphytes growing closer to the sediments, and tight negative relationships between NR activity and water column $\mathrm{NH}_{4}{ }^{+}$concentration, support the hypothesis that higher $\mathrm{NH}_{4}{ }^{+}$concentration close to the sediment suppresses NR activity in macroalgal epiphytes on $P$. sinuosa leaves. The lower NR activity overall and lack of significant vertical variation in NR activity in algae growing on Amphibolis antarctica could relate to higher $\mathrm{NO}_{3}^{-}$availability or confounding effects of macroalgal species composition and distribution. The potential $\mathrm{NO}_{3}^{-}$assimilation by macroalgal epiphytes on seagrasses represents a major sink for watercolumn $\mathrm{NO}_{3}{ }^{-}$, but $\mathrm{NO}_{3}{ }^{-}$capture and incorporation by macroalgal epiphytes may be more limited by $\mathrm{NO}_{3}{ }^{-}$ availability than assimilation capacity.

Acknowledgements. E.B.Y. was supported by a NERC UK grant to J.A.B. and M.J.D. and a travel grant from Edith Cowan University's Faculty Visiting Research Fellows Scheme. B.v.E. was supported by an Australian Postgraduate Award. T. Reid made the biomass measurements and M.L. Cambridge provided expert advice and field assistance. At Monash University, Victoria, Australia, J. Beardall generously provided laboratory space and assisted with algal collection, J. Baldwin provided equipment loan and C. Ashburner assisted with algal identification.

\section{LITERATURE CITED}

Araki S, Ikawa T, Oohusa T, Nisizawa K (1979) Some enzymic properties of nitrate reductase from Porphyra yezoensis Uneda f. narawaensis Miura. Bull Jpn Soc Sci Fish 45: 919-924

Balandin T, Aparicio PJ (1992) Regulation of nitrate reductase in Acetabularia mediterranea. J Exp Bot 43:625-631

Berges JA, Cochlan WP, Harrison PJ (1995) Laboratory and field responses of algal nitrate reductase to diel periodicity in irradiance, nitrate exhaustion, and the presence of ammonium. Mar Ecol Prog Ser 124:259-269

Boon PI (1986) Nitrogen pools in seagrass beds of Cymodocea serrulata and Zostera capricorni of Moreton Bay, Australia. Aquat Bot 25:1-19

Brush MJ, Nixon SW (2002) Direct measurements of light attenuation by epiphytes on eelgrass Zostera marina. Mar Ecol Prog Ser 238:73-79
Cambridge ML, Hocking PJ (1997) Annual primary production and nutrient dynamics of the seagrasses Posidonia sinuosa and Posidonia australis in south-western Australia. Aquat Bot 59:277-295

Corzo A, Niell FX (1991) Determination of nitrate reductase activity in Ulva rigida C. Agardh by the in situ method. J Exp Mar Biol Ecol 146:181-191

Davison IR, Stewart WDP (1984a) Studies on nitrate reductase activity in Laminaria digitata (Huds.) Lamour. I. Longitudinal and transverse profiles of nitrate reductase activity within the thallus. J Exp Mar Biol Ecol 74:201-210

Davison IR, Stewart WDP (1984b) Studies on nitrate reductase activity in Laminaria digitata (Huds.) Lamour. II. The role of nitrate availability in the regulation of enzyme activity. J Exp Mar Biol Ecol 79:65-78

Davison IR, Andrews M, Stewart WDP (1984) Regulation of growth in Laminaria digitata: use of in vivo nitrate reductase activities as an indicator of nitrogen limitation in field populations of Laminaria spp. Mar Biol 84:207-217

Dortch Q (1990) The interaction between ammonium and nitrate uptake in phytoplankton. Mar Ecol Prog Ser 61: 183-201

Dring MJ (1982) The biology of marine plants. Cambridge University Press, Cambridge

Everest SA, Hipkin CR, Syrett PJ (1984) The effect of phosphate and flavin adenine dinucleotide on nitrate reductase activity of some unicellular marine algae. J Exp Mar Biol Ecol 76:263-275

Ganesan M, Mairh OP, Rao PVS (2001) Effect of pre-incubation of nitrate and ammonium in cultures on nitrate reductase activity in marine red algae Gelidiella and Gracilaria from southeast coast of India. Indian J Mar Sci 4:232-236

Gao Y, Smith GJ, Alberte RS (1992) Light regulation of nitrate reductase in Ulva fenestrata (Chlorophyceae). I. Influence of light regimes on nitrate reductase activity. Mar Biol 112: 691-696

Hauxwell J, Cebrian J, Furlong C, Valiela I (2001) Macroalgal canopies contribute to eelgrass (Zostera marina) decline in temperate estuarine ecosystems. Ecology 82:1007-1022

Haxen PG, Lewis OAM (1981) Nitrate assimilation in the marine kelp, Macrocystis angustifolia (Phaeophyceae). Bot Mar 24:631-635

Holmes RM, Aminot A, Kerouel R, Hooker BA, Peterson BJ (1999) A simple and precise method for measuring ammonium in marine and freshwater ecosystems. Can J Fish Aquat Sci 56:1801-1808

Hurd CL, Berges JA, Osborne J, Harrison PJ (1995) An in vitro nitrate reductase assay for marine macroalgae: optimization and characterization of the enzyme for Fucus gardneri (Phaeophyta). J Phycol 31:835-843

Johannes RE, Pearce AF, Weibe WJ, Crossland CJ, Rimmer DW, Smith DF, Manning C (1994) Nutrient characteristics of well-mixed coastal waters off Perth, Western Australia. Estuar Coast Shelf Sci 39:273-285

Kendrick GA, Lavery PS (2001) Assessing biomass, assemblage structure and production of algal epiphytes on seagrasses. In: Short FT, Coles RG (eds) Global seagrass research methods. Elsevier Science, Amsterdam, p 199-222

Kendrick GA, Campey M, Lavery P, Westera M, Wheeler K (1998) Shells and dredging environmental management programme. Project S1: Ecological significance of seagrass. Task 7: Primary production. Final Report to Cockburn Cement, Perth

Kraemer GP, Mazzella L, Alberte RS (1997) Nitrogen assimilation and partitioning in the Mediterranean seagrass Posidonia oceanica. PSZN I: Mar Ecol 18:175-188 
Lartigue J, Sherman TD (2002) Field assays for measuring nitrate reductase activity in Entermorpha sp. (Chlorophyceae), Ulva sp. (Chlorophyceae) and Gelidium sp. (Rhodophyceae). J Phycol 38:971-982

Lavery PS, Vanderklift MA (2002) A comparison of spatial and temporal patterns in epiphytic macroalgal assemblages of the seagrasses Amphibolis griffithii and Posidonia coriacea. Mar Ecol Prog Ser 236:99-112

Lavery P, Westera M, Kendrick GA, Brearley A, Campey M, Hegge B, Hillman K (1998) Shells and dredging environmental management programme. Project S1: Ecological significance of seagrass. Task 5: Calcium carbonate and nitrogen turnover on Success Bank, Western Australia. Final Report to Cockburn Cement, Perth

Lee KS, Dunton KH (1999) Inorganic nitrogen acquisition in the seagrass Thalassia testundinum: development of a wholeplant nitrogen budget. Limnol Oceanogr 44:1204-1215

Libes M (1986) Productivity-irradiance relationships of Posidonia oceanica and its epiphytes. Aquat Bot 26:285-306

Lopes PA, Oliveira MC, Colepicolo P (1997) Diurnal fluctuation of nitrate reductase activity in the marine red alga Gracilaria tenuisipitata (Rhodophyta). J Phycol 33: 225-231

Marbà N, Walker DI (1999) Growth, flowering and population dynamics of temperate Western Australian seagrasses. Mar Ecol Prog Ser 184:105-118

McGlathery KJ (2001) Macroalgal blooms contribute to the decline of seagrass in nutrient-enriched coastal waters. J Phycol 37:453-456

Paling EI, McComb AJ (1994) Nitrogen and phosphorus uptake in seedlings of the seagrass Amphibolis antarctica in Western Australia. Hydrobiologia 294:1-4

Paling EI, McComb AJ (2000) Autumn biomass, belowground productivity, rhizome growth at bed edge and nitrogen content in seagrasses from Western Australia. Aquat Bot 67:207-219

Editorial responsibility: Otto Kinne (Editor-in-Chief), Oldendorf/Luhe, Germany
Parsons TR, Maita Y, Lalli CM (1984) A manual of chemical and biological methods for seawater analysis. Pergamon Press, Oxford

Pedersen MF (1994) Transient ammonium uptake in the macroalga Ulva lactuca (Chlorophyta): nature, regulation and the consequences for choice of measuring technique. J Phycol 30:980-986

Pedersen MF, Paling EI, Walker DI (1997) Nitrogen uptake and allocation in the seagrass Amphibolis antarctica. Aquat Bot 56:105-107

Silberstein K, Chiffings AW, McComb AJ (1986) The loss of seagrass in Cockburn Sound, Western Australia. III. The effects of epiphytes on productivity of Posidonia australis Hook. F. Aquat Bot 24:355-371

Solomonson LP, Barber MJ (1990) Assimilatory nitrate reductase: functional properties and regulation. Annu Rev Plant Physiol Plant Mol Biol 41:225-253

Thomas TE, Harrison PJ (1985) Effect of nitrogen supply on nitrogen uptake, accumulation and assimilation in Porphyra perforata (Rhodophyta). Mar Biol 85:269-278

Thomas TE, Harrison PJ (1988) A comparison of in vitro and in vivo nitrate reductase assays in three intertidal seaweeds. Bot Mar 31:101-107

Touchette BW, Burkholder JM (2001) Nitrate reductase activity in a submersed marine angiosperm: controlling influences of environmental and physiological factors. Plant Physiol Biochem 39:583-593

Trautman DA, Borowitzka MA (1999) Distribution of the epiphytic organisms on Posidonia australis and P. sinuosa, two seagrasses with differing leaf morphology. Mar Ecol Prog Ser 179:215-229

Walker DI, McComb AJ (1988) Seasonal variation in the production, biomass and nutrient status of Amphibolis antarctica (Labill.) Sonder ex Aschers. and Posidonia australis Hook. F. in Shark Bay, Western Australia. Aquat Bot 31: $259-275$

Submitted: July 8, 2003; Accepted: October 21, 2004 Proofs received from author(s): February 17, 2005 